Tsaqofiya : Jurnal Pendidikan Bahasa dan Sastra Arab

Vol. 3 No. 1, 2021, 1-15

P-ISSN : 2685-7022, E-ISSN : 2685-7103

DOI: $10.21154 /$ tsaqofiya.v3i1.64

\title{
Isytiqâq Dalam Bingkai Ilmu Fiqhul Lughah dan Pendapat Para Ulama
}

\author{
Ahmad Sirfi Fatoni \\ Institut Agama Islam Nurul Hakim Lombok Barat \\ ahmadsirfi20@gmail.com
}

\section{Abstract}

This article examines isytiqâq within the framework of Fiqhul lughah and the opinion of scholars. Isytiqâq is important to be studied more deeply because it is one of characteristic of Arabic language and within it we can produce new vocabulary words that have never been found before. The impact is that Arabic language is getting richer and more dynamic. The research method used is descriptive-critical analysis. The data collection technique uses the observation method with the note. The findings obtained are: (1) there are three kinds of isytiqâq: a) Al-isytiqâq al-shaghir, b) Al-isytiqâq al-Kabir, c) Al-isytiqâq al-Akbar, (2) Arab scholars differed on the issue of the origin of isytiqâq and its scope. Some scholars argue that some words are musytaq and some aren't musytaq. Meanwhile, other scholars argue that all words are musytaq. While some others suspect that all words are authentic, there are no words that are musytaq from other words; (3) The scholars who think that some words are musytaq and some aren't musytaq are the opinions of scholars of Bashrah and Kufah. The scholars of Bashrah argue that mashdar is the origin of isytiqâq. Meanwhile, scholars of Kufah argue that fi'il is the origin of isytiqâq; (4) The relationship between language and isytiqâq has a reciprocal relationship.

Keywords: Isytiqâq, Scholars Opinion, Mashdar, Fi'il

\section{Abstrak}

Artikel ini mengkaji isytiqâq dalam bingkai ilmu Fiqhul lughah dan pendapat para ulama. Isytiqâq penting dikaji karena merupakan ciri khas bahasa Arab dan dengannya kita dapat membuat kosakata baru yang sebelumnya belum pernah ditemukan. Dampaknya bahasa Arab semakin kaya dan bersifat dinamis. Metode penelitian yang dipakai adalah deskriptif-analisis kritis. Teknik penjaringan data menggunakan metode simak dengan teknik catat. Temuan-temuan yang didapatkan ialah: (1) isytiqâq mempunyai tiga macam bentuk: a) Al-isytiqâq alshaghir, b) Al-isytiqâq al-Kabir, c) Al-isytiqâq al-Akbar, 2) Ulama Arab berbeda pendapat dalam mengenai asal dari isytiqâq dan cakupannya. Di antara ulama berpendapat bahwa sebagian kata adalah musytaq dan sebagiannya tidak. Sedangkan ulama lain berpendapat semua kata adalah musytaq dan sebagian yang lain menduga bahwa semua kata adalah asli, 3) Para ulama yang berpendapat sebagian kata ada yang musytaq adalah ulama Bashrah dan Kufah. Ulama Bashrah berpendapat mashdar merupakan asal dari isytiqâq. Sedangkan ulama' Kufah berpendapat fi'il merupakan asal dari isytiqâq. 4) Hubungan bahasa dengan isytiqâq bersifat resiprokal.

Kata Kunci: Isytiqâq, Pendapat Ulama, Mashdar, Fi'il 


\section{Pendahuluan}

Banyak orang beranggapan bahwa bahasa Arab itu sulit. Namun, kenyataannya banyak orang yang bisa mempelajari bahasa Arab sedikit demi sedikit sampai akhirnya bisa menekuni dan mendalami keistimewaan yang ada di dalam bahasa Arab itu sendiri. Perlu diketahui bahwa penutur bahasa Arab dari tahun ke tahun semakin meningkat, hal itu dikarenakan bahasa Arab merupakan bahasa Al-Qur'an yang mana mayoritas orang Islam memahami dan menggunakannya dalam ibadahibadah keagamaan. Bahasa Arab juga mempunyai ciri-ciri khusus yang tidak terdapat pada bahasa-bahasa yang lain. Oleh karena keistimewaan dan keunggulannya, akhirnya bahasa Arab menjadi bahasa yang fleksibel, dinamis, mempunyai dominasi dan elastisitas yang signifikan serta sebagai penyampaian dalam ceramah keagamaan di berbagai penjuru dunia. Adapun salah satu keistimewaan bahasa Arab yaitu adanya isytiqâq atau derivasi.

Isytiqâq merupakan salah satu ciri bahasa Arab yang sangat penting dan harus dipelajari oleh setiap mahasiswa, khususnya jurusan bahasa Arab. Isytiqâq hanya dimiliki oleh bahasa Arab dan hampir tidak ditemukan di dalam bahasa-bahasa yang lain. Isytiqâq juga mempengaruhi dalam pembuatan puisi dan prosa. Ketika ada puisi yang diduga qafiyahnya tidak serasi, maka ahli linguistik mempunyai kesempatan untuk merubahnya, salah satunya dengan cara isytiqâq. Oleh karena itu, isytiqâq merupakan salah satu tema yang sangat membantu dan mempengaruhi proses berkembang dan berjalannya bahasa. Berdasarkan latar belakang di atas dan kegelisahan akademik yang tersirat, perlu adanya penelitian yang mendalam terkait isytiqâq. Hal urgen lain yang menjadi sorotan pokok dalam tema isytiqâq ialah perbedaan pendapat para linguis mengenainya. Oleh karena itu, penulis dapat mengambil beberapa rumusan masalah: (1) Bagaimana peta konsep isytiqâq dalam koridor ilmu Fiqhul lughoh? (2) Bagaimana pandangan dan perbedaan pendapat para ulama' bahasa mengenai isytiqâq? (3) Mengapa isytiqâq mempunyai korelasi erat dengan bahasa pada umumnya?

\section{PETA KONSEP ISYTIQÂQ DALAM DISIPLIN ILMU FIQHUL LUGHAH}

Secara etimologi, kata isytiqâq ialah bentuk mashdar dari kata اشتق - يشتَقُ yang berarti "memperoleh, mengasal atau mengambil". Dengan demikian isytiqâq berarti 
"ilmu asal-usul kata". Secara terminologi, para ahli mendefinisikannya dengan berbagai pendapat, diantaranya Ya'qub, isytiqâq adalah:

$$
\text { أخذ كلمة من أخرى بتغيير ما مع التناسب فى المعنى }
$$

Artinya: "Membentuk kata dari kata yang lain dengan berbagai perubahan, namun tetap memiliki hubungan makna."

Di dalam bukunya Auril Bahruddin, isytiqâq adalah:

$$
\text { أخذ كلمة من أخرى، مع تناسب بينهما في المعنى و تغيير في اللفظ }
$$

Artinya: "Membentuk kata dari kata yang lain disertai keserasian antara keduanya dalam makna dan perubahan dalam lafadznya."

Sementara itu Abdus Sobur memberikan definisi isytiqâq ialah pembentukan kata yang cabang dari kata yang asli menurut pondasi dan aturan yang valid, sebagaimana yang terjadi dalam isytiqâqnya isim sifat, isim zaman, isim makan dan yang serupa dengan itu. ${ }^{1}$ Beberapa definisi di atas menjelaskan sebuah proses pembentukan kata yang dapat melahirkan beberapa kata. Antara beberapa kata yang dihasilkan melalui proses pembentukan tersebut tetap memiliki makna yang mirip dengan makna kata dasarnya. Sebagai contoh, akar kata ضرب bisa dibentuk kata-kata sebagai berikut : ضارب، مضروب، مِضرب، اضرب، لا تضرب dan seterusnya. Walaupun bentuk kata tersebut berbeda, namun antara satu kata dengan kata yang lain memiliki hubungan makna, yaitu "pukul".

Hal yang perlu diutarakan juga bahwa para ulama modern telah mencurahkan segala daya upaya dan pemikirannya tentang kajian terhadap fenomena-fenomena linguistik dalam rangka membedah dan mengetahui secara detail terkait apa yang terjadi dalam lafadz-lafadz, uslub-uslub dan shigot-shigot, terkhusus dalam bahasa Arab. Hal yang diperbincangkan di sini termasuk salah satuya ialah fenomena isytiqâq yang mana dianggap sebagai tema yang amat urgen dalam rangka melahirkan dan memproduksi lafadz-lafadz dan shighot-shighot baru dalam bahasa Arab. Sementara itu, jika ditelisik lebih lanjut hubungan antara isytiqâq dengan qiyas sangatlah kental. Hal itu disebabkan isytiqâq merupakan suatu proses kegiatan dalam rangka melahirkan suatu lafadz dari lafadz yang lain atau suatu shighot dari shighot yang lain. Sedangkan qiyas adalah sebuah aturan atau undang-undang dasar yang mana

${ }^{1}$ Auril Bahruddin, Fiqhullughoh Al-Arabiyyah (Malang: Uin Malang Press, 2009), hlm. 111 
proses isytiqâq dibangun atas dasar itu, supaya sesuatu yang baru yang mana ditelorkan dari proses itu diterima dan dikenal luas oleh para ahli bahasa. Oleh karena itu, qiyas dianggap sebagai teori, sementara isytiqâq dianggap sebagai proses pengaplikasiannya. Dari uraian tersebut, kita dapat mengetahui dan mengatakan bahwa bahasa Arab merupakan lughah isytiqâqiyyah baik dari unsur utama maupun unsur pendukungnya. ${ }^{2}$

Menurut جوزيف فندريس term isytiqâq secara etimologi diartikan sebagai ilmu yang mengkaji tentang mufrodat. Dia berkata: "Sesungguhnya isytiqâq ialah sebuah ilmu sejarah yang memberikan batasan dan definisi terkait shighotnya setiap kata pada masa yang sangat klasik di mana diizinkannya info-info sejarah untuk sampai kepada ilmu tersebut. Ilmu tersebut juga mengkaji metode atau cara yang mana suatu kata berjalan bersamaan dengan perubahan yang terjadi di dalamnya termasuk dari segi makna dan segi penggunaan. Perlu diketahui juga bahwa isytiqâq, syautiyyat dan shaut mereka bertiga saling bersandar dengan yang lain, dalam artian bahu membahu untuk membangun suatu rumusan bahasa, termasuk lafadz yang ada di dalamnya. Selama kaidah-kaidah yang berlaku pada rangkaian dan urutan al-aswat dan shighot-shighot nahwu itu masih dalam koridor gambaran-gambaran isytiqâq, maka isytiqâq yang digunakan dengan cara yang baik dan tepat akan memberikan sumbangan untuk ilmu bahasa secara matang." ${ }^{3}$ Oleh sebab itu, tidak berlebihlebihan jika kita mengatakan bahwa isytiqâq dianggap sebagai aktivitas yang sangat bermanfaat untuk menolong sebuah bahasa dalam mencari rumus-rumus dan kosakata baru. Dari proses isytiqâq muncul puluhan bahkan ratusan kosakata baru.

\section{METODE PENELITIAN}

Penelitian ini termasuk penelitian kualitatif yang bersifat deskriptif analisis. Objek penelitiannya ialah tema-tema isytiqâq serta aneka variannya yang terdapat dalam ilmu Fiqhul lughah serta beberapa pendapat para ulama mengenai teori isytiqâq yang masih diperdebatkan dan belum mendapat titik terang. Data-data dalam penelitian ini diambil dan dirujuk dari buku-buku Fiqhul lughah yang valid dan

\footnotetext{
2 Muhammad Sholih Yasin Abbas, "Dhohiratul Isytiqaq Inda Majma' al-Lughah al-'Arabiyyah bi al-Qahirah," Majallah al-Adab, Vol. 109, 2014 M, hlm. 208-209.

${ }^{3}$ Muhammad Sholih Yasin Abbas, "Dhohiratul Isytiqaq Inda Majma' al-Lughah al-'Arabiyyah bi al-Qahirah," Majallah al-Adab, Vol. 109, 2014 M, hlm. 209.
} 
otoritatif. Adapun teknik penjaringan data, penulis menggunakan metode simak dengan teknik catat. Metode simak yaitu suatu metode di mana penjaringan datanya dilakukan dengan menyimak penggunaan bahasa, dalam konteks ini bahasa tulisan yang ada dalam buku. Metode simak juga bisa disebut sebagai metode observasi. Buku-buku yang mengandung tema isytiqâq diteliti, diamati dan dikelompokkan secara tepat oleh penulis. ${ }^{4}$ Hasil pengamatannya yang dilakukan secara terus menerus lalu dituangkan dalam sebuah narasi tulisan secara runtut sehingga mudah dan enak dipahami. Pada akhir tulisan, penulis mengintisarikan seluruh hasil penelitiannya dalam sebuah kesimpulan.

\section{Pembahasan}

\section{Macam-Macam Isytiqâqq}

Secara sederhana, isytiqâq dibagi menjadi tiga macam:

1. Al-Isytiqâq al-Shogir (الإشتقاق الصغير)

Disebut juga dengan al-Isytiqâq al-'Am atau al-Isytiqâq al-Ashgar, yaitu proses pembentukan beberapa kata dari sebuah kata dasar dengan tetap memperhatikan kesamaan urutan morfem tetap seperti yang terdapat pada kata dasarnya. Sebagai contoh morfem كتب, urutan morferm tetap-nya adalah sebagai

berikut: Sf adalah urutan pertama, تurutan kedua, dan Berbagai kata bisa dibentuk dari ketiga morfem tetap tersebut.

Dengan demikian, Al-isytiqâq al-Shogir mencakup Tashrif Isthilahi, misal kita ambil contoh kata ضَرَبَ:

- Fi'il Madhi, contoh ضرب

- Fi'il Mudhori, contoh يضرب

- Fi'il Amar, cotoh اضرب

- Isim Fa'il, contoh ضارب

- Isim Maf'ul, contoh مضروب

${ }^{4}$ Tri Mastoyo Jati Kesuma, Pengantar (Metode) Penelitian Bahasa (Yogyakarta: Carasvatibooks, 2007), hlm. 43. 
- Shifah Musyabbihah bi Ismi al-Fa'il, contoh بخل - بخيل

- Isim Tafdhil, contoh أحسن?

- Isim Zaman, contoh مطلح

- Isim Makan, contoh مغرب

- Isim 'Alat, contoh مفتاح

Dari kitab Fushul Fi Fiqhil Lughoh Al-Arabiyyah disebutkan bahwa isim musytaq itu terbagi menjadi tujuh yaitu:

1. Isim fail, contoh: لعِب -لاعب

2. Isim maful, contoh: درس - مدروس

3. Sifat musyabbihah, contoh: شريف في قول أحد : زيدُ شريفُ النسبِ

4. Siyaghul mubalaghoh, contoh: صبور, أكول, مفضال

5. Isim makan, contoh: مَولد, مَوعِعِ

6. Isim zaman, contoh: مَنصر, مَيْسِرَ

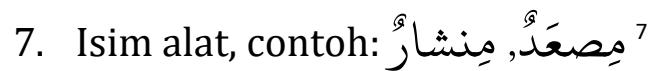

Dari kitab yang sama disebutkan juga al-af'al al-musytaqqah yaitu fi'il-fi'il mazid (fi'il tsulasi mazid, fi'il ruba'i mazid), fi'il mudhori' dan fi'il amr. Fi'il tsulasi mazid terbagi menjadi tiga bagian: (1) mazid dengan satu huruf, contoh: أخرج (2) mazid dengan dua huruf, contoh: تقاتل (3) mazid dengan tiga huruf, contoh: استعظًمَمَ. Adapun fi'il ruba'i mazid terbagi menjadi dua bagian: (1) mazid dengan satu huruf,

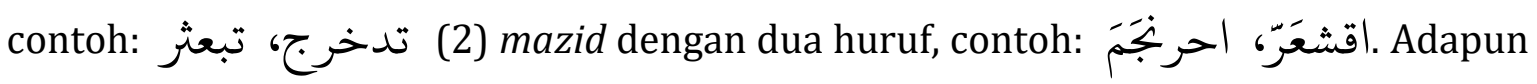

${ }^{5}$ Auril Bahruddin, Fiqhullughoh Al-Arabiyyah (Malang: Uin Malang Press, 2009), hlm. 112.

${ }^{6}$ Muhammad Ma'shum bin Ali, Al-Amtsilah Al-tasyrifiyyah (Jombang: Maktabah wa Mathba'ah Salim Nabhan,1965), hlm. 5.

7 Imil Badi' Ya'qub, Fushul Fi Fiqhil Lughoh Al-Arabiyyah (Tarablas, Lebanon, Al-muassasah alhadistah li al-Kitab, 2008), hlm. 29-31. 
fi'il yang lain adalah fi'il mudhori' contohnya: يدخل, ينطلق, يتمارض, يقابل dan fi'il amr, contohnya yaitu: أشَرَب، استخرِجْ، احِلْ

\section{Al-Isytiqâq al-Kabir (الإشتقاق الكبير)}

Al-isytiqâq al-Kabir disebut juga Al-Qalbu al-Lughowy. Menurut Ya'qub, Alisytiqâqq al-Kabir yaitu:

$$
\text { هو أن يكون بين كلمتين تناسبُ فى اللفظ والمعنى دون ترتيبِ الحروف }
$$

Artinya: "Dua kata yang memiliki persamaan pada lafadz dan makna tanpa memperhatikan susunan huruf." Dengan kata lain, Al-isytiqâq al-Kabir adalah sebuah proses pembentukan kata dalam bahasa Arab dengan cara membolak-balikkan posisi morfem tetapnya, sehingga dapat menimbulkan susunan kata yang baru, namun antara satu dengan yang lain memiliki keterkaitan makna. Contoh, kata حَمِ bisa

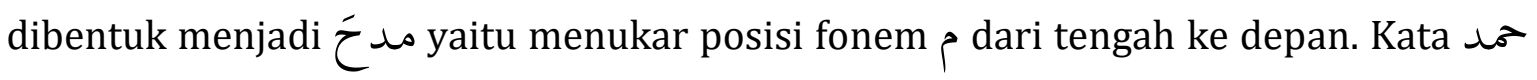
berarti “memuji, berterimakasih", kata مد حuga berarti “memuji”.

Contoh lain, kata خلص bisa dibentuk menjadi لخص yaitu menukar posisi fonem ل dari tengah ke depan. Kata خلص berarti "murni, bersih", kata لخص juga berarti "murni". Contoh lain: جذب, جبذ, بذج, بجذ, ذجب, ذبج, Kita juga bisa memberikan contoh lain:

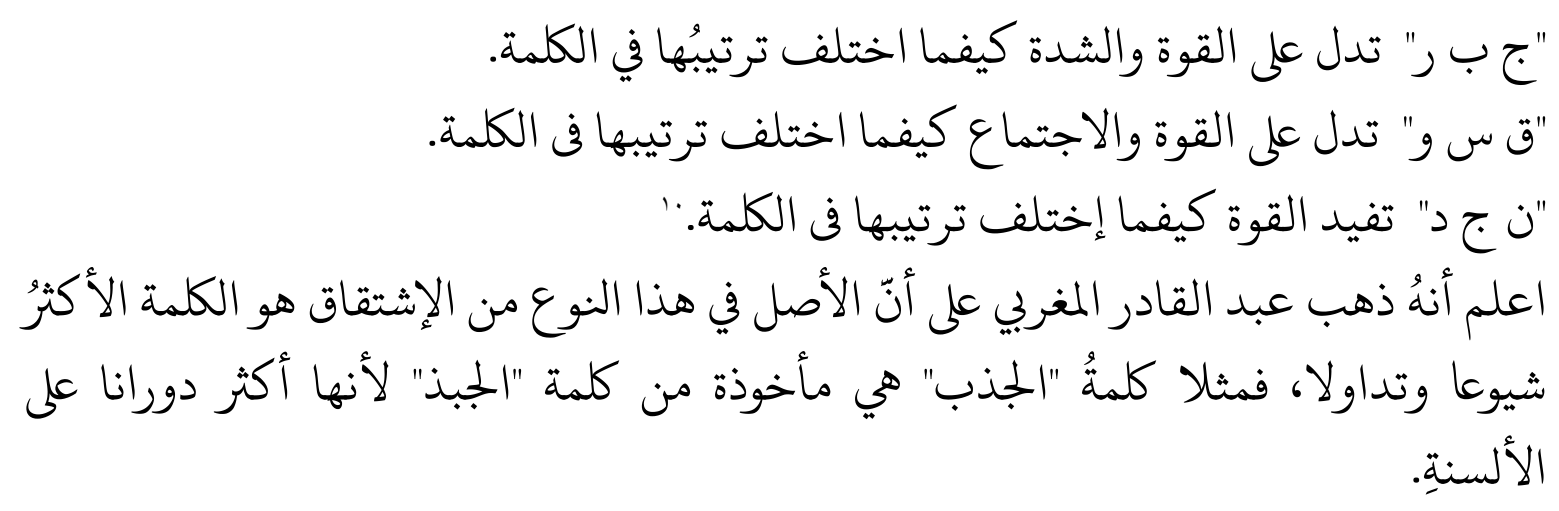

${ }^{8}$ Imil Badi' Ya'qub, Fushul Fi Fiqhil Lughoh....., hlm. 32-40.

${ }^{9}$ Imil Badi' Ya'qub, Fushul Fi Fiqhil Lughoh....., hlm. 42.

10 Ali Abdul Wahid Wafi, Fiqhul Lughoh Athrahu Bi jam'il Lughoh Al-Arabiyyah (Mesir, Multazamatut Thab'i wan Nasyri Lajnatul Bayan Al-Arabi, 1962), hlm. 181. 
Abdul Al-Qadir Al-Maghribi berpendapat bahwa isytiqâq semacam ini yang dianggap asli adalah kata yang paling f'amiliar, sering dipakai dan bersirkulasi secara terus menerus, contohnya: "الجذب" kaslinya adalah "الجبذ" katena tersebut banyak berotasi dalam lidah serta sering dipakai. ${ }^{11}$

\section{Al-Isytiqâq al-Akbar (الإشتقاق الأكبر)}

Menurut Ya'qub, Al-isytiqâq al-Akbar adalah :

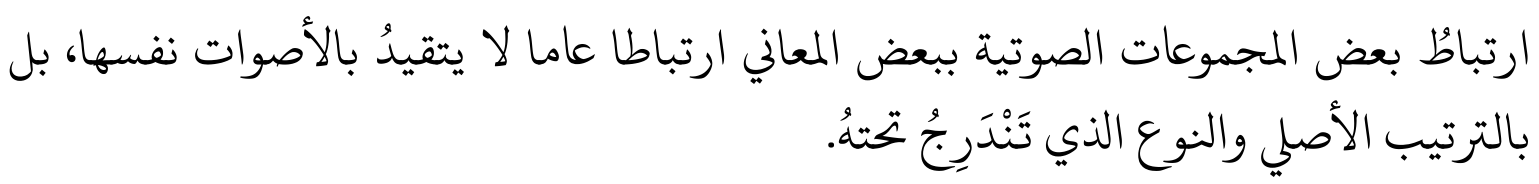

Artinya: "Adanya hubungan umum sebagian satuan bunyi dengan sebagian makna. Hubungan itu tidak terikat oleh bunyi suara, tetapi terikat dengan susunan asalnya serta jenis yang termasuk di dalamnya."

Al-isytiqâq al-Akbar biasanya juga disebut dengan الإبدال yaitu menukar huruf dari sebuah kata dengan huruf lain yang mirip dari segi makhrajnya atau cara mengartikulasikannya sehingga lebih mudah untuk diucapkan. Contoh, pada kata

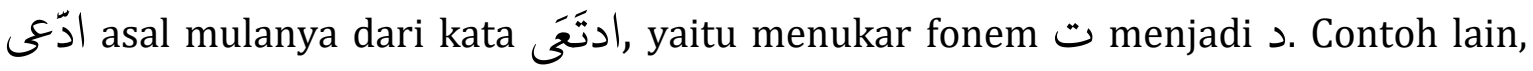
kata اصطنع asal mulanya dari kata اصتنع, yaitu menukar fonem ت اصنع menjadi ط.

Dalam literatur lain, hal yang perlu digarisbawahi bahwa para ulama klasik maupun modern agak berbeda dalam menuangkan pembagiannya terkait isytiqâq. Menurut ulama bahasa klasik, dalam hal ini ialah Ibnu Jinni (Wafat $392 \mathrm{H}$ ), isytiqâq menurutnya dibagi menjadi dua: isytiqâq besar dan isytiqâq kecil. Isytiqâq kecil ialah apa yang terdapat dan terjadi di kalangan manusia pada umumnya dan di kitab-kitab mereka, sebagaimana anda mengambil asal dari beberapa asal, lalu anda mengumpulkannya di antara makna-maknanya meskipun di situ shighot-shighot dan bina'-bina'nya berbeda, itulah yang dinamakan dengan

\footnotetext{
11 Imil Badi' Ya'qub, Fushul Fi Fiqhil Lughoh....., hlm. 43.
} 
isytiqâq kecil. Adapun isytiqâq besar (الاشتقاق الكبير) yaitu sebuah isytiqâq yang mana anda dapat mengambil asal dari al-ushul al-sulasiyyah, lalu anda mengkomplekskannya dan membolak-balikkannya sampai enam kali dalam ikatan satu makna. Itulah yang dinamakan dengan isytiqâq besar menurut Ibnu Jinni. Oleh karena itu, dapat diintisarikan bahwa isytiqâq menurut Ibnu Jinni (representasi ulama bahasa klasik) terbagi menjadi dua: الاشتقاق (2) ,الاشتقاق الصغير أو الأصغرُ (1) الصرفي الكبيرُ أو الأكبو. Yang pertama dapat disebut juga dengan الكُ kedua dapat disebut dengan التقليب المجتمعُ على معنى واحدٍ. Perlu ditekankan di sini bahwa dua macam isytiqâq tersebut merupakan dua dasar atau tiang yang dibuat sandaran dan patokan oleh ahli linguis klasik. ${ }^{12}$

Adapun para ulama bahasa modern, mereka berbeda pendapat tentang macammacam isytiqâq, sebagaimana mereka juga berbeda pendapat tentang batasan istilahistilah dari pengklasifikasian tema isytiqâq. Sebagian dari mereka membagi isytiqâq menjadi tiga macam: (1) al-isytiqâq al-'amm atau al-shogir, (2) al-isytiqâq al-kabir, ialah perputaran pembolak-balikan tiga asal huruf berdasar pada makna satu yang bersifat umum, (3) al-isytiqâq al-akbar atau al-qalbu wa al-ibdal. Di sisi lain, sebagian dari mereka membagi isytiqâq menjadi empat macam: (1) al-isytiqâq al-asghor, atau disebut juga al-shorfi, (2) al-isytiqâq al-kabir, yang dimaksud di sini al-taqlib, (3) alisytiqâq al-kabir atau al-akbar, yang dimaksud adalah al-ibdal, (4) al-isytiqâq alkubbar, yang dimaksud ialah al-naht. ${ }^{13}$ Itulah beberapa pandangan berbeda dari beberapa ulama mengenai klasifikasi tema isytiqâq dan variannya. Meskipun mereka berbeda pandangan mengenai hal tersebut, akan tetapi kalau dirunut dengan konsep yang ada akan terlihat sama dan esensinya pun tidak berbeda jauh.

12 Muhammad Sholih Yasin Abbas, "Dhohiratul Isytiqaq Inda Majma' al-Lughah al-'Arabiyyah bi al-Qahirah," Majallah al-Adab, Vol. 109, 2014 M, hlm. 210-211.

13 Muhammad Sholih Yasin Abbas, "Dhohiratul Isytiqaq Inda Majma' al-Lughah al-'Arabiyyah bi al-Qahirah," Majallah al-Adab, Vol. 109, 2014 M, hlm. 211. 


\section{Perbedaan Pendapat Ulama' Mengenai Isytiqâq}

Para ahli linguistik Arab berbeda pendapat dalam masalah asal dari isytiqâq dan cakupannya. Sebagian ulama' berpendapat bahwa sebagian kata ada yang musytaq dan ada yang tidak musytaq. Sedangkan ulama' yang lainnya berpendapat bahwa semua kata adalah musytaq. Ada juga sebagian ulama' yang menduga bahwa semua kata adalah asli dan tidak ada kata yang musytaq dari kata yang lain.

Adapun ulama' yang berpendapat bahwa sebagian kata ada yang musytaq dan ada yang tidak musytaq adalah pendapat dari ulama Bashrah dan Kufah. Ulama Bashrah berpendapat bahwa mashdar merupakan asal dari isytiqâq. Adapun ulama' Kufah berpendapat bahwa fi'il merupakan asal dari isytiqâq. Masing-masing dari ulama Bashrah maupun Kufah memiliki argumen-argumen mantiqi dan falsafi yang telah diperinci oleh Ibnu Al-Anbari dalam kitabnya: الإنصافُ في مسائلِ الخلافِ بين . Pertentangan ini pun berlanjut sampai sekarang, ada sebagian ulama yang menguatkan madzhab Bashrah dan ada sebagian lainnya yang mendukung madzhab Kufah. ${ }^{14}$

Adapun argumen yang diajukan oleh ahli nahwu Bashrah sebagai berikut: (1) bahwasanya masdar dinamakan sebagai masdar karena dia merupakan sebuah tema dan sekaligus tempat yang dijadikan sumber oleh hewan yang bernama unta. Oleh karena itu, selagi dia dianggap sebagai sumber, maka tidak heran jika fi'il diambil dari masdar tersebut, (2) bahwa masdar itu selalu menunjuk pada zaman yang bersifat mutlak, sementara itu fi'il menunjuk pada zaman tertentu tidak mutlak. Hal yang perlu diketahui di sini bahwa mutlak merupakan asal dari muqayyad, demikian juga terjadi pada masdar yang merupakan asal daripada fi'il, (3) bahwa jika masdar merupakan sesuatu yang musytaq dari fi'il, maka dia wajib menunjukkan sesuatu yang ada pada fi'il dari adanya hadas (peristiwa), zaman dan makna yang ketiga. Hal itu seperti yang terjadi dalam isim-isim fa'il, isim-isim maf'ul yang mana mereka mengindikasikan pada suatu hadas dan dzatnya fa'il atau maf'ul bih. Akan tetapi masdar tidaklah demikian, dia tidak mengandung suatu zaman, maka dari itulah bisa disimpulkan bahwa masdar tidak musytaq dari fi'il, (4) bahwasanya fi'il itu

14 Imil Badi' Ya'qub, Fushul Fi Fiqhil Lughoh Al-Arabiyyah (Tarablas, Lebanon: Al-Muassasah alHadistah li al-Kitab, 2008), hlm. 26-27. 
menyimpan atau mengandung masdar, sementara masdar tidaklah menyimpan atau mengandung fi'il. Hal itu menunjukkan bahwa masdar bukan berasal dari fi'il.

Sementara itu, argumen-argumen yang dituangkan oleh ulama nahwu Kufah yang mengatakan bahwa fi'il merupakan asal dari isytiqâq, sedangkan masdar adalah cabang darinya adalah sebagai berikut: (1) jika kita berkata bahwa masdar diambil dari fi'il, hal itu disebabkan fi'il bisa dikatakan sah atau sohih karena adanya kesahihan dan kevalidan dari fi'il itu sendiri, serta juga karena fi'il bisa ber'illat karena adanya ke'illatannya sendiri. Coba kita perhatikan contoh ini: قاوَمَ - قِوَوامًا , dalam contoh itu masdar bisa dikatakan sah (valid) karena adanya kesahihan fi'il terlebih dahulu. Contoh lain: ققاحَ - قِيَامًا, masdar dalam hal ini dianggap ber'illat karena adanya 'illatnya fi'il terlebih dahulu. Dari situlah dapat diintisarikan bahwa selama kesahihan dan ke'illatan masdar itu bergantung pada kesahihan dan ke'illatan fi'il, maka bisa dikatakan bahwa masdar adalah cabang dari fi'il, (2) karena fi'il tersebut bisa beramal pada masdar, contoh: ضربتُ ضربَّا, dari situ kita bisa mengamati bahwa lafadz ضربا ضربتُ dinasabkan oleh fi'il, dari situlah maka masdar wajib dikatakan cabang dari fi'il bukan sebaliknya. Hal itu berlaku demikian karena derajat 'amil berada sebelum derajat ma'mul, maka dari kasus tersebut fi'il merupakan asal dari masdar, (3) karena masdar dituangkan dalam sebuah kalimat hanya sebagai penguat bagi suatu fi'il, contoh: ضربتُ ضربًا, dan perlu diingat bahwa derajat atau pangkat muakkad berada satu tingkat sebelum derajatnya muakkid, yang mana dalam konteks ini ialah masdar. Dari situlah cukup jelas diketahui bahwa fi'il merupakan asal, sementara masdar ialah cabang darinya, (4) bahwasanya masdar tidak bisa mempersepsikan atau mengangan-angan maknanya selagi terlepas dari pekerjaan si pelaku (فعلُ فاعلٍ), sementara itu fa'il berhak diletakkan padanya shighot فَعََل يَفْعَلْ Oleh karena itulah, fi'il yang mana dengannya bisa diketahui suatu 
masdar dari suatu kata tertentu diklaim menjadi asal atau sumber dari si masdar tadi. $^{15}$

\section{Hubungan Isytiqâq dengan Bahasa}

Bahasa sebagai cermin dari kebudayaan suatu masyarakat. Dengan bahasa dapat diketahui peradaban, struktur masyarakat, situasi politik, kualitas pendidikan dan sastra masyarakat tersebut. Di dalam bahasa terdapat kaidah-kaidah yang mengikat struktur dan bentuk bahasa itu. Dalam bahasa Arab dikenal dengan yang namanya isytiqâq. Oleh karena itu, secara langsung maupun tidak langsung isytiqâq juga mempengaruhi, merubah dan mempunyai hubungan dengan budaya dan bahasa masyarakat tertentu. Dapat dikatakan bahwa bahasa Arab merupakan bagian dari bahasa Semit yang menjadi bahasa yang unik, istimewa dan aneh dengan adanya isytiqâq. Sebagaimana yang kita ketahui, isytiqâq hanya ada dalam bahasa Arab saja. Selain bahasa Arab jika ada kalimat yang seperti isytiqâq, maka tidak diklasifikasikan dalam al-isytiqâq al-shogir, al-isytiqâq al-kabir dan al-isytiqâq al-akbar seperti yang kita bahas sebelumnya.

Isytiqâq mempengaruhi makna secara general dan juga dapat memberikan sumbangan pemikiran dalam bahasa secara luas, khususnya bahasa Arab. Dengan mengetahui isytiqâq, seseorang dapat mengerti bahwa ada ciri khas kesamaan makna bagi huruf atau kata tertentu. Hal ini tidak hanya berlaku pada al-isytiqâq al-kabir, namun juga berlaku pada al-isytiqâq al-shogir. Jadi, isytiqâq merupakan salah satu subkajian dalam bahasa Arab yang sangat berpengaruh dan dapat memperluas pemahaman arti sebuah bahasa itu sendiri. Oleh karena itu, kita perlu mempelajari dan mendalami tema isytiqâq dengan berbagai variasinya sebagai bagian dari pengembangan dan penguatan bahasa itu sendiri.

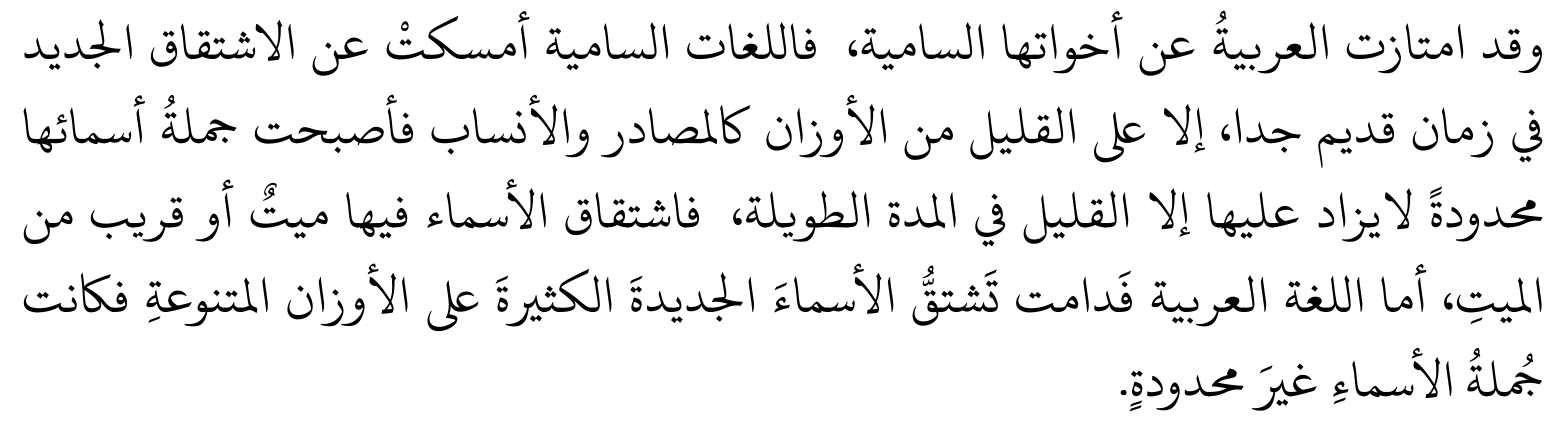

${ }^{15}$ Auril Bahruddin, Fiqhullughoh Al-Arabiyyah (Malang: Uin Malang Press, 2009), hlm. 114-116. 
Artinya: Bahasa Arab telah mempunyai keistimewaan melebihi bahasa-bahasa Semit yang lainnya. Dalam kurun waktu yang sangat lama, bahasa-bahasa Semit sudah memiliki isytiqâq baru tetapi hanya sedikit dari wazan-wazannya seperti masdar dan nasab. Jumlah isim-ism dari wazan tersebut terbatas dalam artian tidak bertambah kecuali hanya sedikit. Hal itu bisa kita lihat dalam kasus Isytiqâqul asma' yang mana sudah hilang atau hampir hilang. Adapun bahasa Arab selalu mengambil atau menurunkan isim-isim baru berdasarkan wazan-wazan yang berbeda. Oleh karena itu, jumlah isim-isim dalam bahasa Arab tidak terbatas (banyak). ${ }^{16}$

Ketika isytiqâq dapat dianggap sebagai hal yang dapat mempengaruhi bahasa walaupun statusnya diperdebatkan, maka akan dibahas pula mengenai pengaruh bahasa terhadap budaya itu sendiri. Bahasa Arab adalah bahasa yang kaya dan melimpah kosa katanya karena adanya isytiqâq. Dengan bahasa ini pula, orang-orang Islam menjadi maju dalam peradabannya. Dalam hal ini, kita bisa ambil contoh AlJabiri yang mengatakan bahwa salah satu sebab majunya peradaban Arab adalah kekuatan lafadz atas bentuk bahasanya. Jadi, dengan bahasa Arab yang baik ini, maka peradaban Arab menjadi maju. Pada masa kemajuan peradaban Arab, hampir mayoritas penduduk Arab menggunakan bahasa Arab, bahkan karya tulis ilmiahpun banyak sekali yang diproduksi dari bahasa Arab di berbagai bidang keilmuan.

Perlu ditekankan di sini juga bahwa bahasa Arab telah mengalami fase sejarah yang sangat panjang sejak nabi Adam sampai zaman sekarang ini. Di sela-sela itulah bahasa Arab mengalami tantangan-tantangan yang sangat dahsyat dari gesekangesekan yang ada termasuk persaingannya dengan bahasa Inggris, yang notabennya diklaim lebih maju dan lebih prestise dibanding bahasa Arab. Perlu diketahui juga, bahasa Arab tetap eksis sampai era ini karena bahasa Arab adalah bahasa Al-Qu'ran yang menjadi rujukan otoritatif bagi umat muslim seluruh dunia. Tak ada seorang pun yang menyangkal kebenaran mutlak Al-Qur'an kecuali hanya segelintir orang saja.

${ }^{16}$ Rajab Abdul Jawad Ibrahim, Dirasah fi Ad-Dalalah wa al-Mu'jam (Kairo, Mesir: Dar al-Ghorib li-At-thaba'ah wa An-Nasyr wa- at-Tauzi', 2001), hlm. 113. 


\section{Simpulan}

Dari penelitian di atas, maka dapat disimpulkan sebagai berikut: Secara sederhana, macam-macam isytiqâq ada tiga: (1) Al-isytiqâq al-shaghir, (2) Al-isytiqâq al-Kabir, (3) Al-isytiqâq al-Akbar. Para ahli linguistik Arab berbeda pendapat dalam masalah asal dari isytiqâq dan cakupannya. Sebagian ulama' berpendapat bahwa sebagian kata ada yang musytaq dan ada yang tidak musytaq. Sedangkan ulama' yang lain berpendapat bahwa semua kata adalah musytaq. Sementara sebagian ulama' yang lain menduga bahwa semua kata adalah asli, tidak ada kata yang musytaq dari kata yang lain.

Kesimpulan lain, secara langsung maupun tidak langsung isytiqâq juga mempengaruhi, merubah serta mempunyai hubungan dengan budaya dan bahasa masyarakat tertentu. Bahasa Arab yang merupakan bagian dari bahasa Semit Selatan menjadi bahasa yang istimewa dan unik dengan adanya isytiqâq ini. Sebagaimana yang kita ketahui, isytiqâq hanya ada dalam bahasa Arab saja. Selain bahasa Arab jika ada kalimat yang seperti isytiqâq, maka tidak diklasifikasikan dalam kelompok isytiqâq seperti yang kita bahas sebelumnya. Akan tetapi hanya bersifat kebetulan saja terjadi di selain bahasa Arab, sehingga tidak begitu diperhitungkan keberadaannya.

Hal yang perlu ditekankan di sini, mengapa bahasa Arab semakin berkembang? Karena bahasa Arab merupakan bahasa yang digunakan oleh Al-Qur'an yang mana semua polemik di dunia ini bisa dicari solusinya dalam Al-Qu'ran. Oleh karena itu, bahasa Arab tetap eksis sampai saat ini bahkan sudah masuk dalam salah satu bahasa resmi PBB pada tanggal 18 Desember 1973 M. Hal itu dapat terjadi karena jumlah penutur bahasa Arab yang berkembang pesat dari tahun ke tahun sehingga membuat PBB memutuskan untuk menjadikan bahasa ini sebagai salah satu bahasa resmi PBB. Bahasa Arab bersanding dengan 5 bahasa resmi PBB lainnya (Bahasa Inggris, Tionghoa, Perancis, Rusia dan Spanyol). Perlu disampaikan juga bahwa adanya teori isytiqâq juga memperkuat prestise dan kedudukan bahasa Arab di kancah global dengan bukti-bukti yang telah diulas sebelumnya. Teori isytiqâq ini bisa memunculkan puluhan bahkan ratusan kosakata bahasa Arab baru yang mana hanya berasal atau berakar pada satu kata saja. 
TSAQOFIYA: Jurnal Pendidikan Bahasa dan Sastra, 3 (1), 2021

\section{Daftar Pustaka}

Abbas, Muhammad Sholih Yasin. “Dhohiratul Isytiqâq Inda Majma' al-Lughah al'Arabiyyah bi al-Qahirah," Majallah al-Adab, Vol. 109, 2014 M.

Bahruddin, Auril. Fiqhul Lughoh Al-Arabiyyah. Malang: Uin Malang Press. 2009.

Ibrahim, Rajab Abdul Jawad. Dirasah fi Ad-Dalalah wa al-Mu'jam. Kairo, Mesir: Dar alGhorib li-At-Thaba'ah wa An-Nasyr wa- at-Tauzi'. 2001.

Kesuma, Tri Mastoyo Jati. Pengantar (Metode) Penelitian Bahasa. Yogyakarta: Carasvatibooks. 2007.

Ma'shum, Muhammad, Al-Amtsilah Al-tasyrifiyyah. Jombang: Maktabah wa Mathba'ah Salim Nabhan. 1965.

Wafi, Ali Abdul Wahid. Fiqhul lughoh Athrahu Bijam'i al-Lughoh Al-Arabiyyah. Mesir: Multazam al-Thab'i wa al-Nasyri Lajnatul Bayan Al-Arabi. 1962.

Ya'qub, Imil Badi'. Fushul Fi Fiqhil Lughoh Al-Arabiyyah. TArablas, Lebanon: AlMuassasah al-Hadistah li al-Kitab. 2008. 